\title{
ANALISIS PENGETAHUAN LINGKUNGAN DAN PERILAKU RAMAH LINGKUNGAN BERDASARKAN GENDER DAN TINGKAT PENDIDIKAN DI KOTA PEKANBARU
}

\author{
Julina \\ FakultasEkonomidanIlmuSosialUIN Suska Riau \\ Email: julina@uin-suska.ac.id
}

\begin{abstract}
This study attempted to investigate whether there are differences in knowledge about the environment and eco-friendly purchasing behavior based on gender and education. Data were collected using questionnaire containing questions about environmental knowledge and eco-friendly behavior based on previous research. Collected data were analyzed using descriptive and quantitative techniques. Multivariate Analysis of Variance (MANOVA) was used to determine the influence of gender and education level of knowledge and eco-friendly behavior. Results of univariate model testing found that in terms of gender, the gender differences found significant influence on both purchase decisions of environmentally friendly and environmental knowledge. While the the education level influence on of environmental knowledge, but it does not affect the environmentally friendly purchasing decisions. Based on these findings, it is expected that integrate relevant aspects of environmental conservation in all levels of education, and so is strengthening the role of each gender to support the creation of an enabling environment both for current and future generations.
\end{abstract}

Keywords:Environmental Knowledge, Environmental Product Purchase Decision, Level of Education, Gender.

\section{PENDAHULUAN}

Kerusakan lingkungan merupakan isu yang akhir-akhir ini mendapat perhatian dari semua kalangan. Berdasarkan sistem-sistem nilai yang mendalam, pengetahuan dan sikap merupakan hal yang penting karena potensi dampak yang ditimbulkannya pada perilaku. Namun beberapa peneliti menyatakan bahwa meskipun perilaku ramah lingkungan memiliki dampak yang positif, terkadang hal tersebut tidak menjamin rendahnya dampak dari perilaku tersebut terhadap lingkungan. Pengetahuan lingkungan dan sikap ramah lingkungan sangat terkait dan saling memperkuat terutama dalam pencarian informasi tentang isu-isu lingkungan. Masyarakat yang tidak mengetahui bahwa perilakunya dapat berkontribusi pada kerusakan lingkungan, akan terus berperilaku seperti itu. Oleh karena itu, sosialiasi untuk meningkatkan pengetahuan penting untuk dilakukan. Meningkatnya pengetahuan, diharapkan akan berdampak pada sikap terhadap lingkungan sehingga keharmonisan antara manusia dan alam tetap terjaga.

Seiring dengan perkembangan teknologi, isu penting saat ini adalah apakah masyarakat dapat mengandalkan sematamata pada perkembangan teknologi dan peningkatan eco efisiensi untuk mencapai keberlanjutan lingkungan atau apakah solusi terstruktur yang melibatkan pengurangan konsumsi pribadi dan pertumbuhan ekonomi yang diharapkan. Namun demikian, terlepas dari adanya kemajuan teknologi, 
pengetahuan yang ramah lingkungan dan perilaku yang ramah lingkungan tetap merupakan unsur yang penting untuk dilakukan.

Berdasarkan pada literatur sebelumnya, terdapat kemungkinan bahwa tingkat pendidikan dan gender akan mempengaruhi pengetahuan dan perilaku ramah lingkungan. Tujuan penelitian ini adalah untuk mengetahui apakah tingkat pendidikan dan gender juga akan mempengaruhi pengetahuan dan perilaku ramah lingkungan di Kota Pekanbaru. Perilaku ramah lingkungan dapat berupa aktivitas memisahkan sampah organik dan anorganik, melakukan daur ulang, aktif bergabung dengan organisasi lingkungan, dan keputusan membeli produk ramah lingkungan. Produk ramah lingkungan adalah produk yang dampaknya terhadap kerusakan lingkungan lebih sedikit dibandingkan produk yang telah ada atau yang biasa dikonsumsi masyarakat. Penelitian memfokuskan pada perilaku ramah lingkungan yang berupa keputusan membeli produk ramah lingkungan.

\section{Pengetahuan Lingkungan}

Menurut Zsoka et al (2013) pengetahuan lingkungan bermakna pengetahuan dan kesadaran tentang permasalahan lingkungan dan solusinya. Pada umumnya dimensi paling penting dari kesadaran lingkungan setiap individu adalah pengetahuan lingkungan, nilai-nilai, kesediaan untuk bertindak dan perilaku aktual yang dipengaruhi oleh beberapa faktor termasuk elemen niat dan situasi. ${ }^{1}$

Selanjutnya Tan (2011) menyatakan pengetahuan adalah jumlah informasi yang ada di memori seseorang yang mempengaruhi cara di mana konsumen menafsirkan dan menilai pilihan yang tersedia. Secara konseptual, pengetahuan konsumen dapat dibagi menjadi dua komponen: pengetahuan obyektif dan pengetahuan subjektif. Pengetahuan obyektif mengacu pada isi dan organisasi pengetahuan (pengetahuan faktual) yang disimpan dalam memori seseorang. Hal ini mengacu pada apa yang seorang individu benar-benar tahu tentang jenis produk/masalah/objek. Sedangkan pengetahuan subjektif mengacu pada persepsiatau penilaian individu tentang apa yang mereka tahu dan berapa banyak mereka tahu tentang produk/masalah/objek. ${ }^{2}$

Schahn and Holzer (1990) menyatakan terdapat dua jenis pengetahuan lingkungan yaitu pengetahuan abstrak (pengetahuan yang terkait dengan isu-isu lingkungan, masalah, penyebab, dan solusi) dan pengetahuan konkrit (seperti pengetahuan faktual). 3 Menurut Noor et al (2012) pengetahuan dikenali dalam riset konsumen sebagai karakteristik yang mempengaruhi semua tahap dalam pengambilan keputusan. ${ }^{4}$ 
Pengetahuan dan Pendidikan Lingkungan

Pendidikan lingkungan diasumsikan mempunyai dampak yang signifikan terhadap kesadaran lingkungan, gaya hidup sehari-hari, dan perilaku pelajar. Beberapa institusi pendidikan yang lebih tinggi telah mengakui pentingnya mengintegrasikan isuisu sustainability kedalam pendidikan untuk membuat dampaknya menjadi fokus dan eksplisit. Hasil penelitian Zsoka et al., (2013) menemukan adanya korelasi yang kuat antara intensitas pendidikan lingkungan dan pengetahuan lingkungan siswa. Hal ini sebagian dikarenakan pendidikan lingkungan sendiri dan sebagian lagi disebabkan oleh motivasi intrinsik yang lebih tinggi dari siswa-siswa yang berkomitmen yang berpartisipasi sukarela dalam pendidikan lingkungan, khususnya di tingkat universitas. Fokus pada pendidikan lingkungan penting dalam membentuk sikap konsumsi berkelanjutan (sustainable consumption). Membahas isu-isu konsumerisme dalam pendidikan lingkungan sangat meningkatkan kesadaran pada kebutuhan perubahan konsumsi yang terkait gaya hidup. Asumsi utama dibelakang penelitian ini adalah intensitas keterlibatan dalam pendidikan lingkungan adalah faktor yang signifikan dalam membentuk perilaku dan opini siswa mengenai isu-isu lingkungan. ${ }^{5}$

Terkait dengan pengetahuan lingkungan siswa, Asunta (2004) mengobservasi pelajar di Finlandia dan Jerman yang berusia 13-15 tahun. Hasil penelitian menemukan bahwa jumlah sumber untuk mendapatkan informasi tentang lingkungan semakin meningkat sesuai dengan kelas siswa. ${ }^{6}$ Selanjutnya Michalos et al membandingkan perilaku ramah lingkungan dan berkelanjutan antara orang dewasa dan siswa yang berumur 10-18 tahun. Bagi orang dewasa memiliki sikap ramah lingkungan dan berkelanjutan adalah determinan perilaku yang jauh lebih penting dibandingkan dengan pengetahuan. Akan tetapi, bagi siswa SMA pentingnya sikap dan pengetahuan sebagai pendorong perilaku ramah lingkungan sama-sama penting. ${ }^{7}$

Selain faktor-faktor internal yang dicerminkan dalam pengetahuan, sikap, dan nilai-nilai, beberapa faktor-faktor eksternal juga diketahui mempengaruhi perilaku ramah lingkungan. Menurut Fliegenshcnee dan Schelakovsky (1998) hal ini meliputi 80\% dari kesadaran lingkungan individu. Faktorfaktor penting tersebut adalah norma-norma, tekanan, dan tradisi yang ditransmisikan oleh lingkungan sosial. Perilaku siswa terbukti sangat kuat didorong oleh lingkungan terdekat termasuk keluarga, teman, tetangga, dan pendidikan. Kagawa (2007) menemukan bahwa siswa kemungkinan melakukan aktivitas-aktivitas ramah lingkungan (seperti mendaur ulang, hemat air dan energi, menggunakan transportasi publik, dan membeli produk- 
produk organik, sehat, dan diperdagangkan dengan adil) yang mensyaratkan perubahan kecil dalam gaya hidup. ${ }^{8}$

Boyes et al (2008) membandingkan manfaat yang dipersepsikan dengan aktvitas tertentu yang dilakukan untuk mengurangi perubahan iklim. Hasil penelitiannya menemukan bahwa kerelaan untuk melakukan perilaku tertentu sering melampaui manfaat perilaku tersebut terhadap perubahan iklim yang dipersepsikan. Aktivitas-aktivitas tertentu yang membutuhkan sedikit usaha dan menimbulkan sedikit ketidaknyamanan (seperti mematikan peralatan yang tidak dipakai, melakukan daur ulang) adalah aktivitas yang paling sering dilakukan. Namun, pada umumnya siswa tidak bersedia untuk merubah kebiasaan bepergian dengan mobil meskipun aktivitas ini dipandang sangat berpengaruh terhadap pencegahan perubahan iklim. Responden juga mengekspresikan ketidakrelaan untuk memilih solusi politik seperti meningkatkan pajak lingkungan dan mengetatkan peraturan lingkungan, meskipun perubahan ini dipersepsikan efektif. 9

Jelasnya, pendidikan lingkungan akan berdampak pada perilaku ramah lingkungan siswa dalam beberapa cara, termasuk transfer pengetahuan dan nilai-nilai, juga melalui penyediaan contoh-contoh dan membentuk sekolah sebagai setting sosial. Temuantemuan penelitian yang disitasi dalam makalah ini juga menemukan bahwa ketertarikan pada topik-topik lingkungan dan komitmen pada lingkungan penting dalam menentukan hubungan antara pengetahuan lingkungan dan perilaku ramah lingkungan. Hal ini membuktikan bahwa tantangan baru bagi pendidikan lingkungan adalah bagaimana melakukan sesuatu yang lebih jauh daripada hanya sekedar melakukan transfer pengetahuan.

Sebagai konsekuensi dari pembahasan sebelumnya, tantangan terbesar bagi pendidikan lingkungan adalah bagaimana mendorong gaya hidup ramah lingkungan dan mengungari gaya hidup yang tidak ramah lingkungan dengan menyediakan sarana-sarana yang cukup efektif untuk membuat dampak sosial yang lebih luas. Penekanan kebutuhan menghubungkan antara area kognitif dan afektif secara strategis pada pendidikan lingkungan. hal ini juga didukung oleh Alvarez Suarez dan Vega Marcote (2010) yang menguji dengan eksperimen model didaktif pada siswa, menyimpulkan bahwa metode pengajaran yang berfokus pada sikap dapat lebih sukses dalam mendorong perubahan perilaku siswa dibandingkan penggunaan alat-alat yang semata-mata hanya berorientasi pada pengetahuan. ${ }^{10}$

Sejalan dengan Leeming dan Porter (1997), Kagawa (2007) menyatakan bahwa dalam dunia yang berubah sangat cepat dan tidak pasti, pendidikan yang lebih tinggi 
perlu memainkan peran penting dalam membantu siswa menjadi masyarakat yang aktif dan bertanggungjawab. Agar pendidikan lingkungan memperkuat tanggung jawab merupakan hal yang penting baik pada siswa maupun mahasiswa dimana pendekatan-pendekatan yang inovatif diperlukan untuk secara efektif mempersiapkan siswa berhadapan dengan isu-isu lingkungan dan keberlanjutannya. ${ }^{11}$

Menurut Zsoka et al (2013), belakangan ini, pendidikan tinggi untuk pengembangan berkelanjutan (Higher Education for Sustainable Development atau disingkat HESD) telah muncul sebagai bidang ilmu yang berusaha memahami bagaimana keberlanjutan dapat ditingkatkan dalam kurikulum dan aktivitas operasional di institusi pendidikan tinggi. Satu tujuan utama dari HESD adalah untuk memainkan peran tradisional melakukan transformasi masyarakat dan melayani barang-barang publik yang lebih banyak. Sementara itu, menurut Zilahyi dan Huisingh (2009) universitas bergerak lebih jauh dari model-model ilmiah terdahulu dan menyadari bahwa peran mereka dalam masyarakat lebih luas dibandingkan normanorma awal. ${ }^{12}$

Di Indonesia, internalisasi nilai-nilai peduli lingkungan saat ini gencar dilakukan melalui Program Adiwiyata. Program ini diterapkan pada setiap tingkat pendidikan dasar dan menengah. Sementara di tingkat universitas, tidak ada program khusus seperti sekolah Adiwiyata namun dalam bentuk ranking bagi universitas yang memperhatikan lingkungan.

Menurut Zsoka et al (2013) Universitas memiliki tantangan yang sulit: integrasi perspektif yang berbeda dan konsep-konsep sustainability membuat pemikiran yang holistik dan sistemik dan membutuhkan praktik-praktik pembelajaran inovatif yang radikal. Pentingnya memahami sikap dan perilaku siswa terhadap lingkungan dan menemukan cara yang efektif untuk mempengaruhi perilaku ini melalui pendidikan merupakan suatu perdebatan.

\section{Pengetahuan Lingkungan dan Gender}

Pengetahuan yang dimiliki laki-laki dan perempuan menunjukkan adanya perbedaan dalam keahlian yang dimiliki. Beberapa peneliti menganggap laki-laki memiliki keahlian numerik sementara perempuan memiliki keahlian verbal. Dalam topik lingkungan, berdasarkan penelitian terdahulu, bukti-bukti empiris menunjukkan bahwa laki-laki memiliki pengetahuan lingkungan yang lebih tinggi dibandingkan perempuan. Arcury (1990) menyatakan bahwa gender seseorang dapat menjadi faktor yang membedakan jumlah pengetahuan lingkungan yang dimilikinya. ${ }^{13}$ Gendall dan Smith (1995) membandingkan pengetahuan lingkungan pada enam negara. Dari keenam negara tersebut, laki-laki 
cenderung memiliki tingkat pengetahuan yang lebih tinggi dibanding perempuan. ${ }^{14}$ Tikka et al. (2000) menemukan bahwa pengetahuan tentang alam dan lingkungan sepertinya bergantung pada gender karena rata-rata nilai pengetahuan yang dimiliki oleh laki-laki lebih tinggi daripada perempuan. ${ }^{15}$ Penelitian yang dilakukan Mesir oleh Briggs et al. (2003) menemukan bahwa pengetahuan lingkungan perempuan terbatas dibandingkan pengetahuan lingkungan yang dimiliki laki-laki. ${ }^{16}$

Serupa dengan hasil-hasil penelitian sebelumnya, Mostafa (2007) juga menemukan perbedaan yang signifikan antara laki-laki dan perempuan terkait dengan pengetahuan lingkungan. skor ratarata pengetahuan lingkungan laki-laki sebesar 20.428 dan perempuan sebesar 17.080 diuji menggunaka Anova. Hasilnya nya dengan nilai signifikan $<0.001$ menyatakan terdapat perbedaan yang signifikan antara laki-laki dan perempuan dalam pengetahuan lingkungan yang dipersepsikan. ${ }^{17}$

\section{Perilaku Ramah Lingkungan}

Shrum, McCarty, dan Lowrey (1995:72) menyatakan konsumen yang ramah lingkungan adalah siapa saja yang perilaku pembeliannya dipengaruhi oleh perhatian terhadap lingkungan. Dalam penelitian ini, perilaku pembelian ramah lingkungan konsumen tidak hanya dipengaruhi oleh orientasi ramah lingkungan, akan tetapi juga dipengaruhi oleh variabel lainnya. 18 Selanjutnya Mainieri, Barnett, Valdero, Unipan, dan Oskamp (1997:190) menyatakan konsumerisme lingkungan (pembelian ramah lingkungan) adalah kegiatan membeli dan mengkonsumsi produk yang ramah terhadap lingkungan. Definisi ini selanjutnya juga digunakan oleh beberapa peneliti lain seperti Gupta dan Ogden (2006:199); Tan (2011:15); dan Saleki, Saleki, danRahimi(2012:279). ${ }^{19}$

Pada tahun yang sama, Robert dan Bacon (1997) mendefinisikan konsumen yang sadar ekologis sebagai seseorang yang membeli (atau menghindari) produk dan jasa yang dianggap memiliki dampak positi (atau negatif) terhadap lingkungan. ${ }^{20 S e l a n j u t n y a, ~}$ Soonthonsmai (2001) mengutip pendapat dari Anderson dan Cunningham (1972) mendefinisikan konsumen ramah lingkungan sebagai seseorang yang perilaku konsumsinya secara sadar diusahakan untuk memiliki efek yang positif ataupun netral terhadap bumi, lingkungan, dan masyarakat. Kedua definisi ini menggambarkan hal yang sama dimana konsumen mempertimbangkan efek dari pola konsumsinya terhadap lingkungan. ${ }^{21}$

\section{Perilaku Ramah lingkungan dan Tingkat Pendidikan}

Upaya-upaya untuk membentuk perilaku ramah lingkungan telah dilakukan 
oleh berbagai pihak. Direktorat Jenderal Pendidikan Dasar dan Menengah Departemen Pendidikan Nasional (Ditjen Dikdasmen Depdiknas), menetapkan bahwa penyampaian mata ajar tentang kependudukan dan lingkungan hidup secara integratif dituangkan dalam kurikulum tahun 1984 dengan memasukkan materi kependudukan dan lingkungan hidup kedalam semua mata pelajaran pada tingkat menengah umum dan kejuruan. Tahun 1989/1990 hingga 2007, Ditjen Dikdasmen Depdiknas, melalui Proyek Pendidikan Kependudukan dan Lingkungan Hidup (PKLH) melaksanakan program Pendidikan Kependudukan dan Lingkungan Hidup; sedangkan Sekolah Berbudaya Lingkungan (SBL) mulai dikembangkan pada tahun 2003 di 120 sekolah. Sampai dengan berakhirnya tahun 2007, proyek PKLH telah berhasil mengembangkan SBL di 470 sekolah, 4 Lembaga Penjamin Mutu (LPMP) dan 2 Pusat Pengembangan Penataran Guru (PPPG).

Prakarsa Pengembangan Lingkungan Hidup juga dilakukan oleh LSM. Pada tahun 1996/1997 terbentuk Jaringan Pendidikan Lingkungan yang beranggotakan LSM yang berminat dan menaruh perhatian terhadap Pendidikan Lingkungan Hidup. Hingga tahun 2010, tercatat 150 anggota Jaringan Pendidikan Lingkungan (JPL, perorangan dan lembaga) yang bergerak dalam pengembangan dan pelaksanaan pendidikan lingkungan hidup. Sedangkan tahun 1998 2000 Proyek Swiss Contact berpusat di VEDC (Vocational Education Development Center) Malang mengembangkan Pendidikan Lingkungan Hidup pada Sekolah Menengah Kejuruan melalui 6 PPPG lingkup Kejuruan dengan melakukan pengembangan materi ajar PLH dan berbagai pelatihan lingkungan hidup bagi guru-guru Sekolah Menengah Kejuruan termasuk guru SD, SMP, dan SMA.

Pada tahun 1996 disepakati kerjasama pertamaantara Departemen Pendidikan Nasional dan Kementerian Negara Lingkungan Hidup, yang diperbaharui pada tahun 2005 dan tahun 2010. Sebagai tindak lanjut dari kesepakatan tahun 2005, padatahun 2006 Kementerian Lingkungan Hidup mengembangkan program pendidikan lingkungan hidup pada jenjang pendidikan dasar dan menengah melalui program Adiwiyata. Program ini dilaksanakan di 10 sekolah di Pulau Jawa sebagai sekolah model dengan melibatkan perguruan tinggi dan LSM yang bergerak di bidang Pendidikan Lingkungan Hidup.

Tidak hanya pada level dikdasmen, konsep ramah lingkungan telah mendapatkan perhatian pula dari berbagai pihak, termasuk para akademisi. Gerakan kampus hijau muncul pada awal tahun 1990an. Sejak kemunculanya, bermunculan berbagai ide seperti menggagas visi dan mengartikulasikan kebutuhan kampus untuk menggabungkan semua jenis inovasi untuk 
mengurangi keseluruhan dampak lingkungan. Melalui gerakan ini, diharapkan kampus penuh dengan bangunan ramah lingkungan, sistem energi terbarukan, makanan lokal organik, lanseka porganik, diperkaya dengan keanekaragaman hayati asli, sistem transportasi rendah polusi, jalur sepeda, tangki air hujan penyimpanan, sistem pengolahan air abu-abu dan hitam, investasi wakaf sosial, praktekkimia hijau, laboratorium nol limbah padat, produk pembersih hijau, dan rumah kaca yang rendah gas (GHG), dan ide-ide lainnya (Sharp, 2009).22

Di Indonesia, penilaian atas green campus diinisasi oleh Universitas Indonesia melalui sebuah pengukuran green metric yang menggunakan beberapa kriteria. Kriteria yang digunakan untuk mengukur tingkat ramah lingkungan suatu kampus antara lain dari berdasarkan setting dan infrastruktur, energi dan perubahan iklim, pengelolaan sampah, pengelolaan air, transportasi, dan pendidikan. Setting dan infrastruktur secara spesifik mengukur lokasi kampus, iklim, luas kampus, luas bangunan, jumlah mahasiswa, jumlah karyawan (staf dan dosen), luas area bangunan, luas hutan, luas area yang dapat menyerap air, dan persentase biaya untuk pemeliharaan lingkungan. Energi dan dan perubahan iklim antara lain mengukur efisiensi energi yang digunakan, kebijakan penggunaan energi terbarukan, biaya listrik per tahun, program konservasi energi, gedung ramah lingkungan, adaptasi dan mitigasi perubahan iklim, dan kebijakan pengurangan emisi gas rumah kaca. Kriteria pengolahan sampah mensyaratkan kampus memiliki program daur ulang, pengolahan sampah organik dan anorganik, dan kebijakan untuk mengurangi kertas dan plastik dalam aktivitas sehari-hari di kampus. Pengelolaan air terdiri dari dua kriteria yaitu program konservasi air dan penggunaan air pipa. Dari sisi transportasi, beberapa ukuran kampus ramah lingkungan adalah jumlah kendaraan yang dimiliki kampus (bus dan mobil), jumlah mobil yang masuk kampus, jumlah sepeda yang dimiliki, kebijakan transportasi yang dirancang untuk membatasi jumlah kendaraan yang digunakan dalam area kampus, kebijakan membatasi area parkir, penyediaan bus kampus, dan kebijakan area sepeda dan pejalan kaki dalam lingkungan kampus. untuk kriteria pendidikan, aspek-aspek yang diukur antara lain jumlah mata kuliah yang berkenaan dengan lingkungan, jumlah dana riset terkait lingkungan, jumlah publikasi tentang lingkungan, dan jumlah organisasi mahasiswa.

Di tahun 2014, sebanyak 301 universitasdari 61 negara mengambil bagian, jumlah ini meningkat dibandingkan tahun lalu (215 universitas dari 49 negara. University of Nottingham (UK) menduduki ranking pertama dengan nilai 7.521 , diikuti oleh University College Cork National 
University of Ireland (Ireland) dengan nilai 7,328, dan Northeastern University (USA) pada posisi ketiga dengan nilai 7.170. Nilai ini diperoleh dari informasi yang disediakan oleh universitas secara online yang meliputi 6 kategori. Kategori tersebut masing-masing diberi bobot dengan pembagian sebagai berikut: Setting dan Infrastuktur (15\%), Energidan perubahan iklim (21\%), managemen limbah (18\%), penggunaan $\operatorname{air}(10 \%)$, transportation $(18 \%)$, dan pendidikan (18\%).

Menurut Rappaport (2008), terdapat beberapa alasan kampus menerapkan konsep "Green Campus", antara lain:

1. Mahasiswa dimasa mendatang tertarik pada isu lingkungan

2. Melakukan sesuatu yang benar baik secara lokal maupun global konsisten dengan agend aksi sosial kampus.

3. Banyak berjalan dan menggunakan sepeda akan meningkatkan kesehatan

4. Melestarikan air menghasilkan berbagai penghematan: biaya air, biaya saluran pembuangan, dan menurunkan biaya energi.

5. Kampus dengan program lingkungan menggunakan kampus sebagai labor pembelajaran, menghubungkan mahasiswa dengan alam, mendiskusikan nilai-nilai lingkungan.

6. Contoh-contoh perilaku ramah lingkungan memperkaya pembahasan materi dikampus, misalnya mahasiswa ekonomi belajar analisis biaya manfaat dengan menilai pilihan alternatif lantai dan mereka mendapatkan kepuasan ketika hasil karya mereka mempengaruhi keputusan universitas.

\section{Perilaku Ramah lingkungan dan Gender}

Tikkaet al. (2000) telah membuktikan bahwa pada sampel masyarakat di barat, perempuan mengekspresikan sikap yang lebih positif terhadap lingkungan dibandingkan laki-laki.Zeleznyet al. (2000) memberikan bukti tambahan bahwa perempuan memiliki sikap lingkungan yang lebih tinggi dibandingkan laki-laki di 14 negara (Argentina, Canada, Columbia, Costa Rica, the DominicanRepublic, Ecuador, El Salvador, Mexico, Panama, Paraguay,Peru, Spain, the United States and Venezuela). ${ }^{23}$

$$
\text { Mohai (1992) dan Stern }
$$

menemukan bahwa perempuan lebih perhatian pada isu-isu lingkungan dibandingkan laki-laki dan bahwa terdapat perbedaan kepercayaan dan nilai antara lakilaki dan perempuan terkait lingkungan. Berdasarkan review yang mendalam, Davidson dan Freudenberg menyimpulkan bahwa pada lingkungan tertentu, perempuan mengekspresikan perhatian lingkungan yang lebih besar dibanding laki-laki. Penelitian yang dilakukan RiecharddanPeterson (1998) menggunakan 231 siswa menemukan bahwa siswa perempuan memiliki persepsi risiko lingkungan yang lebih tinggi dibanding siswa laki-laki. Penjelasan teoritis untuk perbedaan gender melibatkan peningkatan 
pengetahuan dan toleransi kemajuan teknologi, dukungan untuk pertumbuhan ekonomi, dan persepsi risiko lingkungan yang lebih rendah bagi laki-laki (Blocker and Eckberg, 1997). Misalnya, kepercayaan pada ilmu dan teknologi menyatakan bahwa perempuan kemungkinan mempunyai kekurangan dalam ilmu dan teknologi, sehingga lebih perhatian pada permasalahan lingkungan dan lebih sedikit kemungkinan untuk mendukung kesesuaian teknologi (Davidson and Freudenburg, 1996). Beberapa tulisan dari kelompok ekofeminisme juga menyatakan bahwa perempuan berpotensi lebih perhatian terhadap lingkungan dibandingkan laki-laki karena orientasi biospheric (Merchant, 1979). ${ }^{24}$

\section{METODE}

Penelitian ini berlokasi di Kota Pekanbaru. Data dikumpulkan menggunakan kuesioner yang memodifikasi instrumen dari penelitian sebelumnya. Sumber data terdiri dari data primer dan sekunder. Data primer diperoleh dari hasil penyebaran kuesioner, sementara data sekunder berasal dari berbagai macam dokumentasi yang diperoleh dari berbagai sumber. Teknik pengambilan sampel menggunakan aksidental sampling. Sebanyak 88 orang berpartisipasi dalam penelitian ini. Data yang telah terkumpul kemudian dianalisis menggunakan teknik deskriptif dan kuantitatif. Manova digunakan untuk mengetahui pengaruh gender dan tingkat pendidikan terhadap pengetahuan dan perilaku ramah lingkungan.

\section{HASIL PENELITIAN DAN PEMBAHASAN}

Pembahasan hasil penelitian dimulai dengan membahas identitas responden dan tabulasi silang antara berbagai variabel yang dipilih dalam penelitian ini. Berdasarkan data pada Tabel 1, responden laki-laki dalam penelitian ini berjumlah lebih sedikit dibandingkan perempuan. Tingkat pendidikan terakhir mayoritas SMA atau sederajat. Untuk responden perempuan, mayoritas pendidikan tertinggi juga SMA.

\section{Tabel 1}

Data Responden Berdasarkan Pendidikan dan Gender

\begin{tabular}{llrrr}
\hline & & \multicolumn{2}{c}{ Pendidikan } & \multirow{2}{*}{ Total } \\
& & Universitas & SMA & \\
\hline Jenis & Laki-laki & 10 & 18 & 28 \\
Kelamin & Perempuan & 29 & 31 & 60 \\
Total & & 39 & 49 & 88 \\
\hline
\end{tabular}


Tabel 2 selanjutnya menampilkan skor rata-rata untuk variabel pengetahuan lingkungan subyektif bagi perempuan dan laki-laki. Variabel ini diukur menggunakan lima pernyataan dimana setiap jawaban sangat setuju diberi skor lima dan sangat tidak setuju diberi skor satu untuk pernyataan-pernyataan yang bersifat positif. Untuk pernyataan yang bersifat negatif, pemberian skor merupakan kebalikannya dimana jawaban sangat setuju memperoleh skor satu sementara jawaban sangat tindak setuju memperoleh skor lima.

Pernyataan mengenai responden mengetahui istilah dan simbol ramah lingkungan memperoleh nilai rata-rata 3.62 bagi responden perempuan dan 3.68 untuk responden laki-laki. Hal ini berarti, laki-laki secara subyektif merasa lebih mengetahui istilah dan simbol ramah lingkungan dibandingkan perempuan. Namun selisih skor diantara keduanya tidak terlalu tinggi. Selanjutnya untuk pernyataan mengenai produk yang dapat mengurangi sampah responden laki-laki juga memiliki skor ratarata yang lebih tinggi. Pernyataan ketiga merupakan pernyataan negatif mengenai kesulitan dalam mencari informasi tentang produk ramah lingkungan. Hasil perhitungan skor rata-rata perempuan lebih tinggi dari laki-laki yang berarti perempuan merasa sulit mencari informasi tentang lingkungan. pernyataan selanjutnya tentang isu-isu lingkungan juga menunjukkan lakilaki memiliki skor yang lebih tinggi dibanding perempuan. Pernyataan terakhir yaitu mengenai bagaimana mendaur ulang juga diperoleh skor rata-rata laki-laki yang lebih tinggi dari perempuan.

Tabel 2

Skor Rata-rata Pengetahuan Lingkungan Berdasarkan Gender

\begin{tabular}{|c|c|c|c|c|c|c|c|c|}
\hline \multirow[b]{2}{*}{ No } & \multirow[b]{2}{*}{ Indikator/item pertanyaan } & \multirow{2}{*}{$\begin{array}{l}\text { Jenis } \\
\text { Kelamin }\end{array}$} & \multicolumn{5}{|c|}{ Alternatif Jawaban } & \multirow[b]{2}{*}{$\begin{array}{c}\text { Rata- } \\
\text { rata }\end{array}$} \\
\hline & & & $\begin{array}{l}\text { Sangat } \\
\text { Setuju }\end{array}$ & Setuju & $\begin{array}{l}\text { Cukup } \\
\text { Setuju }\end{array}$ & $\begin{array}{l}\text { Tidak } \\
\text { Setuju }\end{array}$ & $\begin{array}{c}\text { SangatTi } \\
\text { dakSetuj } \\
\mathbf{u}\end{array}$ & \\
\hline \multirow{2}{*}{ PL1 } & \multirow{2}{*}{$\begin{array}{l}\text { Mengetahuiistilahdansimbolpr } \\
\text { odukramahlingkungan }\end{array}$} & Perempuan & 6 & 31 & 18 & 4 & 1 & 3,62 \\
\hline & & Laki-laki & 3 & 16 & 6 & 3 & 0 & 3,68 \\
\hline \multirow{2}{*}{ PL2 } & \multirow{2}{*}{$\begin{array}{l}\text { Mengetahuimemilihproduk } \\
\text { yang mengurangisampah }\end{array}$} & Perempuan & 10 & 25 & 18 & 7 & 0 & 3,63 \\
\hline & & Laki-laki & 5 & 15 & 6 & 2 & 0 & 3,82 \\
\hline \multirow{2}{*}{ PL3 } & \multirow{2}{*}{$\begin{array}{l}\text { Mencaritahuprodukramahling } \\
\text { kungansangatmembingungkan }\end{array}$} & Perempuan & 2 & 23 & 25 & 9 & 1 & 2,73 \\
\hline & & Laki-laki & 3 & 13 & 7 & 4 & 1 & 2,54 \\
\hline \multirow[b]{2}{*}{ PL4 } & \multirow[b]{2}{*}{ Mengetahuiisu-isulingkungan } & Perempuan & 7 & 27 & 23 & 3 & 0 & 3,63 \\
\hline & & Laki-laki & 8 & 15 & 5 & 0 & 0 & 4,11 \\
\hline \multirow{2}{*}{ PL5 } & \multirow{2}{*}{$\begin{array}{l}\text { Mengetahuibagaimanamendau } \\
\text { rulang }\end{array}$} & Perempuan & 5 & 13 & 31 & 10 & 1 & 3,18 \\
\hline & & Laki-laki & 4 & 15 & 5 & 4 & 0 & 3,68 \\
\hline
\end{tabular}


Selanjutnya Tabel 3 menampilkan skor rata-rata pengetahuan lingkungan berdasarkan pendidikan terakhir. Dalam penelitian ini, tingkat pendidikan yang diteliti dikelompokkan pada dua kategori saja. Kategori pertama yaitu responden yang telah mencapai gelar sarjana, baik strata satu, dua mapun tiga. Kategori kedua yaitu responden yang menempuh pendidikan paling tingg SMA atau sederajat.

Pernyataan mengenai responden mengetahui istilah dan simbol ramah lingkungan memperoleh nilai rata-rata 3.77 bagi responden dengan pendidikan terakhir S1 atau diatasnya, dan 3.53 untuk responden dengan pendidikan terakhir SMA atau dibawahnya. Hal ini berarti, responden yang telah menyelesaikan program sarjana secara subyektif merasa lebih mengetahui istilah dan simbol ramah lingkungan dibandingkan responden dengan pendidikan maksimal SMA atau sederajat. Selanjutnya untuk pernyataan mengenai produk yang dapat mengurangi sampah responden tamatan universitas juga memiliki skor rata-rata yang lebih tinggi. Pernyataan ketiga merupakan pernyataan negatif mengenai kesulitan dalam mencari informasi tentang produk ramah lingkungan. Hasil perhitungan skor rata-rata responden yang telah menyelesaikan program sarjana lebih tinggi dari responden dengan pendidikan terakhir SMA. Hal ini berarti meskipun tingka pendidikan lebih tinggi, responden tetap merasa sulit mencari informasi tentang lingkungan. Pernyataan selanjutnya tentang isu-isu lingkungan juga menunjukkan responden dengan tingkat pendidikan yang lebih tinggi memiliki skor yang lebih tinggi pula dibanding responden dengan pendidikan terakhir SMA. Pernyataan terakhir yaitu mengenai bagaimana mendaur ulang juga diperoleh skor rata-rata lebih tinggi bagi responden dengan tingkat pendidikan sarjana dibandingkan responden dengan pendidikan terakhir SMA.

Tabel 3

Skor Rata-rata Pengetahuan Lingkungan Berdasarkan Pendidikan Terakhir

\begin{tabular}{|c|c|c|c|c|c|c|c|c|}
\hline \multirow[b]{2}{*}{ No } & \multirow[b]{2}{*}{ Indikator/item pertanyaan } & \multirow[b]{2}{*}{$\begin{array}{l}\text { Pendidikan } \\
\text { Terakhir }\end{array}$} & \multicolumn{5}{|c|}{ Alternatif Jawaban } & \multirow[b]{2}{*}{ Rata-rata } \\
\hline & & & $\begin{array}{l}\text { Sangat } \\
\text { Setuju }\end{array}$ & Setuju & $\begin{array}{l}\text { Cukups } \\
\text { etuju }\end{array}$ & $\begin{array}{l}\text { Tidak } \\
\text { Setuju }\end{array}$ & $\begin{array}{c}\text { SangatTi } \\
\text { dakSetuj } \\
u\end{array}$ & \\
\hline \multirow[t]{2}{*}{ PL1 } & \multirow{2}{*}{$\begin{array}{l}\text { Mengetahuiistilahdansimbolpr } \\
\text { odukramahlingkungan }\end{array}$} & Universitas & 6 & 21 & 10 & 1 & 1 & 3,77 \\
\hline & & SMA & 3 & 26 & 14 & 6 & 0 & 3,53 \\
\hline \multirow[t]{2}{*}{ PL2 } & \multirow{2}{*}{$\begin{array}{l}\text { Mengetahuimemilihprodukda } \\
\text { nkemasan yang } \\
\text { mengurangisampah }\end{array}$} & Universitas & 9 & 17 & 11 & 2 & 0 & 3,85 \\
\hline & & SMA & 6 & 23 & 13 & 7 & 0 & 3,57 \\
\hline \multirow[t]{2}{*}{ PL3 } & \multirow{2}{*}{$\begin{array}{l}\text { Mencaritahuprodukramahling } \\
\text { kungansangatmembingungkan }\end{array}$} & Universitas & 1 & 15 & 15 & 6 & 2 & 2,82 \\
\hline & & SMA & 4 & 21 & 17 & 7 & 0 & 2,55 \\
\hline \multirow[t]{2}{*}{ PL4 } & \multirow[t]{2}{*}{ Mengetahuiisu-isulingkungan } & Universitas & 9 & 18 & 11 & 1 & 0 & 3,90 \\
\hline & & SMA & 6 & 24 & 17 & 2 & 0 & 3,69 \\
\hline
\end{tabular}


Selain variabel pengetahuan lingkungan, penelitian ini juga mengukur perilaku ramah lingkungan berdasarkan gender dan tingkat pendidikan. Tabel 4 menggambarkan data deskriptif responden berdasarkan gender. Terlihat bahwa responden perempuan hanya memiliki skor rata-rata lebih tinggi untuk pernyataan memperhatikan tanggal kadaluwarsa. Selain itu, skor rata-rata lakilaki selalu lebih tinggi untuk semua pernyataan terkait dengan perilaku ramah lingkungan.

Tabel 4

Skor Rata-rata Perilaku Ramah Lingkungan Berdasarkan Gender

\begin{tabular}{|c|c|c|c|c|c|c|c|c|}
\hline \multirow[b]{2}{*}{ No } & \multirow[b]{2}{*}{ Indikator/item pertanyaan } & \multicolumn{7}{|c|}{ Alternatif Jawaban } \\
\hline & & $\begin{array}{l}\text { Jenis } \\
\text { Kelamin }\end{array}$ & $\begin{array}{l}\text { Sangat } \\
\text { Setuju }\end{array}$ & Setuju & $\begin{array}{l}\text { CukupS } \\
\text { etuju }\end{array}$ & $\begin{array}{l}\text { TidakS } \\
\text { etuju }\end{array}$ & $\begin{array}{l}\text { SangatT } \\
\text { idakSet } \\
\text { uju }\end{array}$ & Rata-rata \\
\hline \multirow[t]{2}{*}{1} & \multirow{2}{*}{$\begin{array}{l}\text { Memperhatikansimbol- } \\
\text { simbolprodukramahlingkunga } \\
\mathrm{n}\end{array}$} & Perempuan & 7 & 34 & 12 & 6 & 1 & 3,67 \\
\hline & & Laki-laki & 8 & 13 & 5 & 1 & 1 & 3,93 \\
\hline \multirow[t]{2}{*}{2} & \multirow{2}{*}{$\begin{array}{l}\text { Memperhatikankandungandal } \\
\text { ammakananatauminuman }\end{array}$} & Perempuan & 19 & 28 & 11 & 2 & 0 & 4,07 \\
\hline & & Laki-laki & 13 & 11 & 4 & 0 & 0 & 4,32 \\
\hline \multirow[t]{2}{*}{3} & \multirow{2}{*}{$\begin{array}{l}\text { Memperhatikantanggalkadalu } \\
\text { awarsa }\end{array}$} & Perempuan & 39 & 21 & 0 & 0 & 0 & 4,65 \\
\hline & & Laki-laki & 19 & 8 & 1 & 0 & 0 & 1,36 \\
\hline \multirow[t]{2}{*}{4} & \multirow{2}{*}{$\begin{array}{l}\text { MembeliProdukdengankemasa } \\
\text { ndapat di daurulang }\end{array}$} & Perempuan & 5 & 19 & 22 & 14 & 0 & 3,25 \\
\hline & & Laki-laki & 4 & 9 & 12 & 3 & 0 & 3,50 \\
\hline \multirow[t]{2}{*}{5} & \multirow{2}{*}{$\begin{array}{l}\text { Membeliprodukhematenergim } \\
\text { eskipunmahal }\end{array}$} & Perempuan & 4 & 23 & 20 & 11 & 2 & 3,27 \\
\hline & & Laki-laki & 5 & 8 & 12 & 3 & 0 & 3,54 \\
\hline \multirow[t]{2}{*}{6} & \multirow{2}{*}{$\begin{array}{l}\text { Tidakmembeliprodukdariperu } \\
\text { sahaanbermasalahlingkungan }\end{array}$} & Perempuan & 6 & 31 & 17 & 6 & 0 & 3,62 \\
\hline & & Laki-laki & 11 & 10 & 6 & 1 & 0 & 4,11 \\
\hline
\end{tabular}

Selanjutnya Tabel 5 menampilkan skor rata-rata perilaku ramah lingkungan berdasarkan pendidikan terakhir.

Berdasarkan data pada Tabel 5 skor rata-rata responden dengan tingkat pendidikan sarjana lebih tinggi untuk semua pernyataan yaitu memperhatikan simbol-simbol ramah lingkungan, kandungan makanan atau minuman, tanggal kadaluwarsa, kemasan dapat di daur ulang, membeli produk hemat energi meskipun mahal, dan tidak membeli dari perusahaan yang bermasalah dengan lingkungan.

Tabel 5

Skor Rata-rata Perilaku Ramah Lingkungan Berdasarkan Pendidikan Terakhir

\begin{tabular}{|c|c|c|c|c|c|c|c|c|}
\hline \multirow[b]{2}{*}{$\begin{array}{l}\mathrm{N} \\
\mathrm{o}\end{array}$} & \multirow[b]{2}{*}{ Indikator/item pertanyaan } & \multirow{2}{*}{$\begin{array}{l}\text { Pendidi } \\
\text { kan } \\
\text { Terakhir }\end{array}$} & \multirow[b]{2}{*}{$\begin{array}{l}\text { SangatSet } \\
\text { uju }\end{array}$} & \multirow[b]{2}{*}{$\begin{array}{c}\text { Setu } \\
\text { ju }\end{array}$} & \multicolumn{2}{|c|}{ Alternatif Jawaban } & \multirow[b]{2}{*}{$\begin{array}{l}\text { SangatTidakS } \\
\text { etuju }\end{array}$} & \multirow[b]{2}{*}{$\begin{array}{c}\text { Rat } \\
\text { a- } \\
\text { rata }\end{array}$} \\
\hline & & & & & $\begin{array}{c}\text { CukupSet } \\
\text { uju }\end{array}$ & $\begin{array}{c}\text { TidakSet } \\
\text { uju }\end{array}$ & & \\
\hline \multirow[t]{2}{*}{1} & $\begin{array}{l}\text { Memperhatikansimbol- } \\
\text { simbolprodukramahlingkungan }\end{array}$ & $\begin{array}{l}\text { Universi } \\
\text { tas }\end{array}$ & 4 & 27 & 5 & 2 & 1 & 3,79 \\
\hline & & SMA & 11 & 20 & 12 & 5 & 1 & 3,71 \\
\hline 2 & Memperhatikankandungandalammakananata & Universi & 15 & 18 & 6 & 0 & 0 & 4,23 \\
\hline
\end{tabular}




\begin{tabular}{|c|c|c|c|c|c|c|c|c|}
\hline & uminuman & tas & & & & & & \\
\hline \multirow{3}{*}{3} & & SMA & 17 & 21 & 9 & 2 & 0 & 4,08 \\
\hline & Memperhatikantanggalkadaluawarsa & $\begin{array}{l}\text { Universi } \\
\text { tas }\end{array}$ & 27 & 12 & 0 & 0 & 0 & 4,69 \\
\hline & & SMA & 31 & 17 & 1 & 0 & 0 & 4,61 \\
\hline \multirow[t]{2}{*}{4} & $\begin{array}{l}\text { MembeliProdukdengankemasandapat di } \\
\text { daurulang }\end{array}$ & $\begin{array}{l}\text { Universi } \\
\text { tas }\end{array}$ & 5 & 13 & 15 & 6 & 0 & 3,44 \\
\hline & & SMA & 4 & 15 & 19 & 11 & 0 & 3,24 \\
\hline \multirow[t]{2}{*}{5} & Membeliprodukhematenergimeskipunmahal & $\begin{array}{l}\text { Universi } \\
\text { tas }\end{array}$ & 6 & 18 & 10 & 4 & 1 & 3,62 \\
\hline & & SMA & 3 & 13 & 22 & 10 & 1 & $\begin{array}{c}3,1 \\
4\end{array}$ \\
\hline \multirow[t]{2}{*}{6} & $\begin{array}{l}\text { Tidakmembeliprodukdariperusahaanbermasa } \\
\text { lahlingkungan }\end{array}$ & $\begin{array}{l}\text { Universi } \\
\text { tas }\end{array}$ & 6 & 21 & 12 & 0 & 0 & 3,85 \\
\hline & & SMA & 11 & 20 & 11 & 7 & 0 & 3,71 \\
\hline
\end{tabular}

Sebelum melakukan uji statistik kuantitatif terlebih dahulu dilakukan uji validitas dan reliabilitas instrumen. Uji validitas dimaksudkan agar instrumen yang hendak digunakan mengukur apa yang seharusnya diukur. Sementara uji reliabilitas bertujuan mengukur apakah alat yang sudah valid tadi dapat bekerja dengan baik ataupun tidak. Adapun hasil pengujian validitas dan reliabilitas dapat dilihat pada Tabel 6.

Tabel 6

Hasil Uji Validitas dan Reliabilitas Instrumen

\begin{tabular}{llcc}
\hline No & \multicolumn{1}{c}{ Pernyataan } & $\begin{array}{c}\text { Cronbach's } \\
\text { Alpha }\end{array}$ & $\begin{array}{c}\text { Korelasi } \\
\text { Pearson }\end{array}$ \\
\hline KP1 & Memperhatikan simbol-simbol produk ramah lingkungan & & 0.768 \\
KP2 & Memperhatikan kandungan makanan atau minuman & 0.750 \\
KP3 & Memperhatikan tanggal kadaluarsa & 0.743 & 0.471 \\
KP4 & Membeli produk dengan kemasan yang dapat didaur ulang & & 0.735 \\
KP5 & Membeli produk hemat energi meskipun lebih mahal & 0.626 \\
KP6 & Tidak membeli produk dari perusahaan bermasalah lingkungan & 0.604 \\
PL1 & Mengetahui istilah dan simbol produk ramah lingkungan & & 0.784 \\
PL2 & Mengetahui produk yang mengurangi volume sampah & 0.828 \\
PL3 & Mencari tahu tentang lingkungan sangat membingungkan & 0.762 & 0.617 \\
PL4 & Memahami isu-isu terkait kerusakan lingkungan saat ini & & 0.771 \\
PL5 & Mengetahui bagaimana mendaur ulang sampah dengan tepat & 0.309 \\
\hline
\end{tabular}

Berdasarkan data pada Tabel 6 terlihat bahwa semua item pertanyaan lolos uji validitas dan reliabilitas. Pernyataanpernyataan untuk mengukur variabel pembelian produk ramah lingkungan diwakili enam pernyataan (KP1-KP6), sedangkan untuk pengetahuan ramah lingkungan diwakili oleh lima pernyataan
(PL1-PL5). Pengujian validitas dilakukan menggunakan Korelasi Pearson. Terlihat bahwa semua item mempunyai nilai $>0.3$. Pengujian reliabilitas dilakukan menggunakan Cronbach's Alpha dimana ketentuan yang berlaku umum nilainya harus diatas 0.6. Selanjutnya, untuk mengetahui pengaruh gender dan tingkat 
pendidikan dilakukan dengan uji Multivariate Analysis of Variance (Manova).

Berdasarkan pengolahan data secara multivariat, perbedaan gender tidak memberikan pengaruh yang signifikan terhadap pengetahuan ramah lingkungan dan pembelian produk ramah lingkungan $(0,079>0.05)$. Selain itu tingkat pendidikan juga tidak memberikan pengaruh yang signifikan terhadap pengetahuan ramah lingkungan dan pembelian ramah lingkungan $(0.058>0.05)$. Begitu pula untuk interaksi antara jenis kelamin dan tingkat pendidikan tidak memberikan perbedaan rata-rata pengetahuan ramah lingkungan dan perilaku pembelian ramah lingkungan (0.172> 0.05). Sedikit terdapat perbedaan dengan hasil perhitungan secara univariat. Test of Between Subject Effect pada Tabel 7 menggambarkan pengujian model secara univariat. Perbedaan jenis kelamin memberikan pengaruh yang signifikan terhadap keputusan pembelian (tingkat signifikansi 0.043) dan pengetahuan lingkungan (tingkat signifikansi 0.044). Hal inidilihatdaritarafsignifikansi yang bernilai< 0,05.Sementara itu, perbedaan tingkat pendidikan tidak berpengaruh terhadap keputusan membeli (tingkat signifikansi 0.171) namun berpengaruh terhadap pengetahuan lingkungan (tingkat signifikansi 0.017). Peningkatan pengetahuan tentang masalah lingkungan akan meningkatkan perhatian dan kesadaran masyarakat. Namun kadangkala hal tersebut tidak secara langsung berdampak terhadap perubahan perilaku. Sikap (terkait dengan objek dan situasi kongkrit, baik positif maupun negatif dengan relevansi dan intensitas tertentu) dinilai dalam kaitan dengan pendidikan lingkungan, gaya hidup sadar sosial, kebiasaan konsumsi dan solusi yang berbeda untuk masalah lingkungan. Perubahan dalam sikap dan nilai adalah pendorong yang diperlukan untuk tindakan, tetapi tidak cukup untuk merubah perilaku kearah yang diharapkan.

Tabel 7

Tests of Between-Subjects Effects

\begin{tabular}{|c|c|c|c|c|c|c|}
\hline Source & Dependent Variable & $\begin{array}{c}\text { Type III Sum } \\
\text { of Squares }\end{array}$ & df & Mean Square & $\mathrm{F}$ & Sig. \\
\hline \multirow[t]{2}{*}{ Corrected Model } & Keputusan Pembelian & $86,908^{\mathrm{a}}$ & 3 & 28,969 & 2,833 & 043 \\
\hline & Pengetahuan Lingkungan & $64,099^{\mathrm{b}}$ & 3 & 21,366 & 2,878 &, 041 \\
\hline \multirow[t]{2}{*}{ Intercept } & Keputusan Pembelian & 39140,369 & 1 & 39140,369 & 3827,051 &, 000 \\
\hline & Pengetahuan Lingkungan & 21972,467 & 1 & 21972,467 & 2960,083 &, 000 \\
\hline \multirow[t]{2}{*}{ Jenis Kelamin } & Keputusan Pembelian & 43,228 & 1 & 43,228 & 4,227 &, 043 \\
\hline & Pengetahuan Lingkungan & 30,942 & 1 & 30,942 & 4,168 & 044 \\
\hline \multirow[t]{2}{*}{ Pendidikan } & Keputusan Pembelian & 19,476 & 1 & 19,476 & 1,904 &, 171 \\
\hline & Pengetahuan Lingkungan & 44,134 & 1 & 44,134 & 5,946 & 017 \\
\hline
\end{tabular}




\begin{tabular}{|c|c|c|c|c|c|c|}
\hline Jenis Kelamin * & Keputusan Pembelian & 7,125 & 1 & 7,125 & 697 & ,406 \\
\hline Pendidikan & Pengetahuan Lingkungan & 6,019 & 1 & 6,019 &, 811 & ,370 \\
\hline \multirow[t]{2}{*}{ Error } & Keputusan Pembelian & 859,092 & 84 & 10,227 & & \\
\hline & Pengetahuan Lingkungan & 623,526 & 84 & 7,423 & & \\
\hline \multirow[t]{2}{*}{ Total } & Keputusan Pembelian & 47498,000 & 88 & & & \\
\hline & Pengetahuan Lingkungan & 26495,000 & 88 & & & \\
\hline \multirow[t]{2}{*}{ Corrected Total } & Keputusan Pembelian & 946,000 & 87 & & & \\
\hline & Pengetahuan Lingkungan & 687,625 & 87 & & & \\
\hline
\end{tabular}

a. R Squared $=, 092$ (Adjusted R Squared $=, 059$ )

b. R Squared $=, 093$ (Adjusted R Squared $=, 061$ )

Perbedaan jenis kelamin berpengaruh baik terhadap pengetahuan lingkungan maupun keputusan pembelian ramah lingkungan. Hasil penelitian Lee (2009) menemukan bahwa remaja perempuan memiliki skor yang lebih tinggi dalam perilaku pembelian ramah lingkungan. Variabel lain yang diteliti dalam penelitian ini juga menemukan bahwa remaja perempuan memiliki skor lebih tinggi pada sikap terhadap lingkungan, perhatian pada lingkungan, keseriusan permasalahan lingkungan yang dipersepsikan, tanggungjawab lingkungan yang dipersepsikan, dan pengaruh rekan sebaya. Sebaliknya, remaja laki-laki memiliki skor rata-rata yang lebih tinggi pada identitas diri dalam perlindungan lingkungan. ${ }^{25}$ Literatur dari barat sebagai mana dilaporkan oleh Mainieri et al (1997) juga membuktikan bahwa perempuan lebih berpartisipasi dalam perilaku yang ramah lingkungan secara umum dan konsumsi ramah lingkungan yang spesifik dibandingkan laki-laki. ${ }^{26}$
Zelezny et al. (2000) mengaitkan perbedaan gender dalam tanggung jawab lingkungan yang dipersepsikan kepada orientasi relasional dan ekosentrik yang kuat yang disosialisasikan kepada perempuan sejak mereka kecil. ${ }^{27}$ Konsumen perempuan, dikarenakan orientasi tanggung jawab dan relasional mereka, merupakan kekuatan masyarakat yang potensial untuk meningkatkan budaya lingkungan dalam jaringan sosial mereka di masyarakat. Mereka juga memainkan peran penting sebagai pemimpin opini untuk mempengaruhi pasangan mereka dalam perlindungan lingkungan dan interaksi personal.

Berdasarkan pengujian pengaruh perbedaan tingkat pendidikan terhadap keputusan membeli produk ramah lingkungan, ditemukan bahwa perbedaan tingkat pendidikan tidak berpengaruh terhadap keputusan membeli. Barangkali hal ini lebih didorong oleh faktor-faktor lain seperti kesediaan membayar lebih mahal. Pada umumnya produk ramah lingkungan 
seperti sayur dan buah organik, atau lampu LED memang menetapkan harga yang lebih mahal. Jika pada sayuran dan buah organik harga yang lebih dianggap sepadan dengan manfaat kesehatan yang akan diperoleh, sementara untuk produk lampu LED, harga yang lebih mahal dianggap sepadan dengan manfaat penghematan sumber daya listrik yang digunakan. Faktor lain yang mempengaruhi perilaku pembelian produk ramah lingkungan adalah ketersediaan produk tersebut di pasar yang mudah dijangkau masyarakat.

Hasil temuan selanjutnya dalam penelitian ini adalah perbedaan tingkat pendidikan berpengaruh terhadap pengetahuan lingkungan.Kesimpulan yang diambil oleh Boyes et al (2008) menyatakan bahwa pendidikan lingkungan mempunyai potensi tertinggi untuk mendorong perubahan perilaku dengan aktivitasaktivitas seperti makan daging lebih sedikit atau membayar lebih mahal untuk listrik dengan energi terbarukan dimana siswa sebenarnya mempunyai kesediaan yang rendah untuk melakukannya, akan tetapi perlahan-lahan dapat meningkat seiring dengan manfaat yang dipersepsikan akan diperoleh dari aktivitas-aktivitas tersebut. ${ }^{28}$ Berdasarkan peta pemikiran yang digambarkan oleh siswa (berumur antara 1219 tahun) untuk merepresentasikan konsumsi saat ini dan dimasa yang akan datang, Ben (2004) menemukan bahwa siswa sangat mempercayai bahwa pengembangan teknologi akan mampu menghadapi permasalahan lingkungan di masa mendatang dan konsumsi hanya akan dibatasi oleh batasan finansial. Sebaliknya, kurang dari 20\% siswa di Australia yang diteliti oleh Worsley dan Skrzypiec (1998) memegang pandangan optimis yang sama akan tetapi hal ini tidak berarti bahwa mereka bersedia mengurangi konsumsi mereka. Boyes et al (2008) menemukan bahwa bukan hanya masalah kesediaan remaja untuk mengurangi konsumsi, akan tetapi kesadaran mereka terhadap manfaat pengorbanan yang dilakukan juga masih rendah. Dalam penelitian Kagawa (2007), mahasiswa cenderung setuju dengan pernyataan-pernyataan radikal tentang isuisu lingkungan tetapi menolak untuk membuat perubahan radikal dalam kehidupan pribadi atau pada tingkat komunitas dan sosial. Kebutuhan untuk mempertahankan pertumbuhan ekonomi sebagai tujuan tidak ditanyakan.Penelitian selanjutnya oleh Zsoka et al., (2013) menemukan adanya korelasi yang kuat antara intensitas pendidikan lingkungan dan pengetahuan lingkungan siswa.

Kegagalan untuk membuat koneksi antara konsumerisme dan permasalahan lingkungan sering disebabkan oleh kelemahan dan ketidaktepatan pendidikan lingkungan, mengindikasikan akan kebutuhan untuk merubah fokus pendidikan 
lingkungan agar dapat menciptakan solusisolusi efektif pada isu-isu terkait perhatian pada lingkungan.

\section{KESIMPULAN DAN SARAN}

Penelitian mengenai perilaku ramah lingkungan telah banyak dilakukan. Artikel ini mencoba mengkaji pengetahuan dan perilaku ramah lingkungan berdasarkan gender dan tingkat pendidikan. Pengetahuan dianggap sebagai variabel penting yang ada dalam setiap tahap pengambilan keputusan. Oleh karena itu penting untuk meneliti variabel tersebut sebagai faktor penting yang mempengaruhi perilaku ramah lingkungan. Pengetahuan dapat diperoleh baik melalui institusi formal mulai dari tingkat sekolah dasar sampai dengan universitas, dan dapat pula diperoleh secara informal melalui keluarga, lingkungan, dan berbagai sumber informasi yang saat ini cenderung mudah untuk diakses. Selain dari tingkat pendidikan, terdapat bukti-bukti dari penelitian sebelumnya mengenai perbedaan gender dalam pengetahuan lingkungan dan perilaku ramah lingkungan.

Hasil penelitian ini membuktikan bahwa perbedaan jenis kelamin memberikan pengaruh yang signifikan terhadap keputusan pembelian produk ramah lingkungan dan pengetahuan lingkungan. Sementara itu, perbedaan tingkat pendidikan tidak berpengaruh terhadap keputusan membeli produk ramah lingkungan namun berpengaruh terhadap pengetahuan lingkungan. Meskipun banyak penelitian terdahulu banyak menemukan bukti pengaruh tingkat pendidikan terhadap perilaku ramah lingkungan, namun terkait dengan sikap spesifik dari perilaku ramah lingkungan yaitu perilaku pembelian ramah lingkungan tidak terbukti dalam penelitian ini. Hal ini dapat dipahami karena jika hanya sekedar sikap, hal tersebut masih berada dalam tataran kognitif atau afektif. Sementara perilaku pembelian produk ramah lingkungan sudah mencapai tataran konatif dimana untuk merealisasikan sikap positif menjadi perilaku aktual membeli banyak faktor lain yang turut mempengaruhi. Bahkan dalam beberapa penelitian dicoba untuk mencari variabel moderasi yang dapat memperkuat atau memperlemah hubungan antara sikap dan perilaku seiring dengan munculnya fenomena green gap yaitu tidak sinkronnya antara sikap positif terhadap lingkungan dengan perilaku aktual yang ramah lingkungan.

Pendidikan lingkungan hendaknya dimulai sedini mungkin. Secara informal, pendidikan lingkungan dimulai dari lingkungan keluarga, sementara secara formal dilakukan sejak sekolah. Siswa saat ini akan mempunyai pengaruh penting pada kondisi lingkungan di masa yang akan datang yang akan membuat penggabungan 
dan institusionalisasi isu-isu sustainability ke dalam pendidikan sangat relevan.

Baik dilevel nasional maupun lokal, program sekolah Adiwiyata telah digulirkan untuk memberikan tidak hanya pengetahuan tentang lingkungan, akan tetapi juga bagaimana berperilaku ramah lingkungan. Program ini akan semakin efektif dengan dukungan dari lingkungan terdekat yaitu keluarga agar sinkron dengan program yang digulirkan pihak sekolah. Dalam keluarga peran perempuan menjadi amat penting dimana sebagai istri dapat mempengaruhi perilaku pasangannya maupun sebagai Ibu yang memberikan pendidikan pada anakanaknya. Adanya fakta bahwa laki-laki memiliki pengetahuan lingkungan yang lebih tinggi dibandingkan perempuan dapat menjadi sarana semakin meningkatkan pengetahuan lingkungan melalui sharing pengetahuan lingkungan dengan para perempuan disekitarnya, baik dilingkungan dirumah, masyarakat maupun lingkungan kerja. Selain itu, yang perlu mendapat perhatian adalah pada jenjang universitas, dimana gema program seperti Adiwiyata yang secara nasional tidak ada, namun sebenarnya dapat pula didorong melalui keikut sertaan kampus pada penilaian green campuss yang penyelenggarannya sudah pada taraf internasional.

\section{Endnotes :}

1 Zsoka, A., Szerenyi, Z. M., Szechy, A., \& Kocsis, T. 2013. Greening due to environmental education? Environmental knowledge,attitudes, consumer behavior and everyday pro-environmentalactivities of Hungarian high school and university students, Journal of Cleaner Production, 48, 125-138

2 Tan, Booi-Chen, 2011.The Roles of Knowledge, Threat, and PCE on Green Purchase Behaviour, International Journal of Business and Management, Vol. 6 No. 12. Pp. 14-27

3 Schahn, J., \&Holzer, E. (1990). Studies of Individual Environmental Concern: The Role of Knowledge, Gender,and Background variables. Environment and Behaviour, 22(6), 767-786.

4 Noor, N.A.M., Muhammad, A., Kassim, A., Jamil, C.Z.M., Mat, N., Mat, N., dan Salleh, H.S. 2012. Creating Green Consumers: How Environmental Knowledge and Environmental Attitude Lead to Green Purchase Behaviour?, International Journal of Arts \& Sciences, Vol. 5 No.1. Pp 55-71.

5 Zsoka et al (2013) opcit

6 Asunta, T., 2004. Knowledge sources, attitudes and self-reported behavior ofsecondary-level science students concerning environmental topics. In: Laine, A.,Lavonen, J., Meisalo, V. (Eds.), Current Research on Mathematics and ScienceEducation. University of Helsinki.Research Report 253.

7 Michalos, A.C., Creech, H., McDonald, C., Hatch Kahlke, P.M., 2009. MeasuringKnowledge, Attitudes and Behaviours towards Sustainable Development: twoExploratory Studies.International Institutefor Sustainable Development,Winnipeg.

8 Kagawa, F., 2007.Dissonance in students' perceptions of sustainable development andsustainability.International Journal ofSustainability inHigherEducation, 8,317338.

9 Boyes, E., Skamp, K., Stanisstreet, M., 2008. Australian secondary students' viewsabout global warming: beliefs about actions, and willingness to act. Research inScience Education 39, 661-680. 
10 ÁlvarezSuárez, P., Vega Marcote, P., 2010. Developing sustainable environmentalbehavior in secondary education students (12-16), Analysis of a didacticstrategy.Procedia Social and Behavioral Sciences 2, 3568e3574.

11 Kagawa, 2007, Opcit

12 Zsoka, et al. 2013. Opcit

13 Arcury, T. (1990) Environmental attitudes and environmental knowledge.Human Organization, 49, , 300-304.

14 Gendall, P. \& Smith, T. (1995) Knowledge of scientific and environmentalfacts: a comparison of six countries.Marketing Bulletin, 6, 65-73.

${ }^{15}$ Tikka, P., Kuitunen, M. \&Tynys, S. (2000) Effects of educational backgroundon students' attitudes, activity levels, and knowledge concerningthe environment. Journal of Environmental Education, 31, 1219

16 Briggs, J., Sharp, J., Hamed, N. \&Yacoub, H. (2003) Changing women'sroles, changing environmental knowledge: evidence from Upper Egypt.The Geographical Journal, 169, 313-325

17 Mostafa, M.M. 2007. Gender differences in Egyptian consumers' green purchasebehaviour: the effects of environmental knowledge, concernand attitude, International Journal of Consumer Studies, 31, 220-229

18 Shrum L. J., John A. McCarty, dan Tina M. Lowrey. 1995. Buyer Characteristic of Green Consumer and Their Implication for Advertising Strategy,Journal of Advertising, Vol. XXIV No. 2. Pp 71-82.

${ }^{19}$ Maineri, T., Barnett, E., Valdero, T., Unipan, J. and Oskamp,S. (1997), “Green buying: the influence of environmentalconcern on consumer buying", Journal of Social Psychology,Vol. 137 No. 2, pp. 189-204.

20 Robert, J.A., \& Bacon, D.R. 1997. Exploring Subtle Relationship between Environmental Concern and Ecologically Conscious Consumer Behavior, Journal of Business Research, 40, Pp. 79-89.

${ }^{21}$ Soonthonsmai, V. 2001. Predicting Intention and Behavior To Purchase Environmentally Sound or GreenProducts among Thai consumers: An Application ofthe Theory of Reasoned Action, Dissertation Doctor of Business Administration, The Wayne Huizenga Graduate School of Business and EntrepreneurshipNova Southeastern University.

22 Sharp, L. 2009. Higher education: the quest for the sustainable campus, Sustainability: Science, Practice, \& Policy, Vol. 5 Issue 1, pp. 1-8.

23 Zelezny, L., Chua, P. and Alrich, C. (2000), "Elaborating ongender differences in environmentalism", Journal of SocialIssues, Vol. 56 No. 3, pp. 443-57.

24 Mostafa, M.M. 2007. Gender differences in Egyptian consumers' green purchasebehaviour: the effects of environmental knowledge, concernand attitude, International Journal of Consumer Studies, 31, 220-229.

25 Lee, K. 2009. Gender Differences in Hong Kong Adolescent Consumers' Green Purchasing Behavior, Journal of Consumer Marketing, 26/2, 87-96.

26 Maineri, et al. (1997) Opcit

27Zelezny, L., Chua, P. and Alrich, C. (2000), "Elaborating ongender differences in environmentalism", Journal of Sociallssues, Vol. 56 No. 3, pp. 443-57.

\section{DAFTAR PUSTAKA}

ÁlvarezSuárez, P., Vega Marcote, P., 2010. Developing sustainable environmentalbehavior in secondary education students (12-16), Analysis of a didacticstrategy.Procedia Social and Behavioral Sciences 2, 3568e3574.

Arcury, T. (1990) Environmental attitudes and environmental knowledge.Human Organization, 49, , 300-304.

Boyes, E., Skamp, K., Stanisstreet, M., 2008. Australian secondary students' viewsabout global warming: beliefs about actions, and willingness to act. 
Research inScience Education 39, 661680.

Briggs, J., Sharp, J., Hamed, N. \&Yacoub, H. (2003) Changing women'sroles, changing environmental knowledge: evidence from Upper Egypt.The Geographical Journal, 169, 313-325.

Gendall, P. \& Smith, T. (1995) Knowledge of scientific and environmentalfacts: a comparison of six countries.Marketing Bulletin, 6, 65-73.

Kagawa, F., 2007.Dissonance in students' perceptions of sustainable development andsustainability.International Journal ofSustainability inHigherEducation, 8,317338.

Lee, K. 2009. Gender Differences in Hong Kong Adolescent Consumers' Green Purchasing Behavior, Journal of Consumer Marketing, 26/2, 87-96.

Michalos, A.C., Creech, H., McDonald, C., Hatch Kahlke, P.M., 2009. MeasuringKnowledge, Attitudes and Behaviours towards Sustainable Development: twoExploratory Studies.International Institutefor Sustainable Development,Winnipeg.

Mostafa, M.M. 2007. Gender differences in Egyptian consumers' green purchasebehaviour: the effects of environmental knowledge, concernand attitude, International Journal of Consumer Studies, 31, 220-229

Noor, N.A.M., Muhammad, A., Kassim, A., Jamil, C.Z.M., Mat, N., Mat, N., dan Salleh, H.S. 2012. Creating Green Consumers: How Environmental Knowledge and Environmental AttitudeLead to Green Purchase Behaviour?, International Journal of Arts $\mathcal{E}$ Sciences, Vol. 5 No.1. Pp 55-71.
Robert, J.A., \& Bacon, D.R. 1997. Exploring Subtle Relationship between Environmental Concern and Ecologically Conscious Consumer Behavior, Journal of Business Research, 40, Pp. 79-89.

Schahn, J., \&Holzer, E. (1990). Studies of Individual Environmental Concern: The Role of Knowledge, Gender,and Background variables. Environment and Behaviour, 22(6), 767-786.

Sharp, L. 2009. Higher education: the quest for the sustainable campus, Sustainability: Science, Practice, E Policy, Vol. 5 Issue 1, pp. 1-8.

Shrum L. J., John A. McCarty, dan Tina M. Lowrey. 1995. Buyer Characteristic of Green Consumer and Their Implication for Advertising Strategy,Journal of Advertising, Vol. XXIV No. 2. Pp 71-82.

Soonthonsmai, V. 2001. Predicting Intention and Behavior To Purchase Environmentally Sound or GreenProducts among Thai consumers: An Application ofthe Theory of Reasoned Action, Dissertation Doctor of Business Administration, The Wayne Huizenga Graduate School of Business and EntrepreneurshipNova Southeastern University.

Tan, Booi-Chen, 2011.The Roles of Knowledge, Threat, and PCE on Green Purchase Behaviour, International Journal of Business and Management, Vol. 6 No. 12. Pp. 14-27

Tikka, P., Kuitunen, M. \&Tynys, S. (2000) Effects of educational backgroundon studentsattitudes, activity levels, and knowledge concerningthe environment. Journal of Environmental Education, 31, 12-19.

Zelezny, L., Chua, P. and Alrich, C. (2000), "Elaborating ongender differences in 
environmentalism", Journal of SocialIssues, Vol. 56 No. 3, pp. 443-57.

Zsoka, A., Szerenyi, Z. M., Szechy, A., \& Kocsis, T. 2013. Greening due to environmental education? Environmental knowledge,attitudes, consumer behavior and everyday proenvironmentalactivities of Hungarian high school and university students, Journal of Cleaner Production, 48, 125-138 